\title{
A Review of Swedish Residential Building Stock Research
}

\author{
Mikael Mangold, Chalmers Technical University, Sweden \\ Magnus Österbring, Chalmers Technical University, Sweden \\ Holger Wallbaum, Chalmers Technical University, Sweden
}

\begin{abstract}
Energy usage in the Swedish building stock has changed significantly the last 20 years. The target of reducing the Green Houses Gas (GHG) emissions by 40\% till 2020 seems reachable through improved energy efficiency and a switch to less GHG emitting heat sources. The goal of GHG neutrality by 2050 will however require further initiatives. This paper is primarily a review of the contemporary Swedish building stock state and research. Different research bodies, such as government research institutes, universities, and companies, have different financing and foci. They present their analyses the built environment differently. This paper creates a structure amongst these actors by dividing them in groups and by identifying topics where there are different positions held by researchers and practitioners in the fields related to building stock. Data from Energy Performance Certificates (EPC) is used to display how energy usage varies depending on building age. This gives an indication on how the building stock is developing and what possibilities there are to reach environmental targets.
\end{abstract}

\section{Keywords: State of the Art, Residential Building Stock, Retrofitting, Energy Usage}

\section{Introduction}

1 s climate change research gained acceptance amongst policy makers, the building stock was identified as a priority for decreasing energy usage ${ }^{1}$ and greenhouse gas (GHG) emission (UNEP 2007). Energy usage in the building stock has been seen as an opportunity to profitably reduce CO2 emissions (Mol and Sonnenfeld 2009). Furthermore, European and national energy self-sufficiency is a target of its own (Commission 2000). Consequently there have been a multitude of European and national governmental funding for studies and research in the field of energy usage in the building stock.

In Sweden, The Swedish National Board of Housing, Building, and Planning (Boverket) has conducted a larger survey (Boverket 2010) on energy usage in the building stock called Betsi. Boverket also gather the Swedish Environmental Performance Certification (EPC) data that contain measured energy usage. This state-of-the-art paper attempts to structure and give an overview to research conducted in connection with these reports and databases. New construction of buildings, construction industry policy, and modeling are larger research areas that border to and merge with building stock research, however these areas are not the foci of this paper.

The purpose of the literature review is to set the base for a study on the Gothenburg EPC data merged with energy billing, geographical, and real-estate owner specific data. This larger study will address variance in energy usage in the Gothenburg building stock and gaps in research identified in this paper.

The literature in this paper contains elements that can be separated in the categories of descriptive and prescriptive, see figure 1. The Betsi study by Boverket (2010), and the EPC data gathered is mainly descriptive. There are also other descriptive and empiric research conducted by universities on both the energy usage in the building stock and studies of describing the building stock. The prescriptive studies of energy usage in the building stock tend to focus on refurbishment. This is done in a multitude of disciplines and with different approaches to the subject.

\footnotetext{
${ }^{1}$ A commonly used synonym would be "energy consumption." However "energy usage" is a preferred termed by the authors since energy is strictly not consumed. Using the term 'energy usage' makes it easier to speak about re-usage of energy, such as domestic electricity heating the building; or energy used to pump heat to a district heat system.
}

The International Journal of Environmental Sustainability 


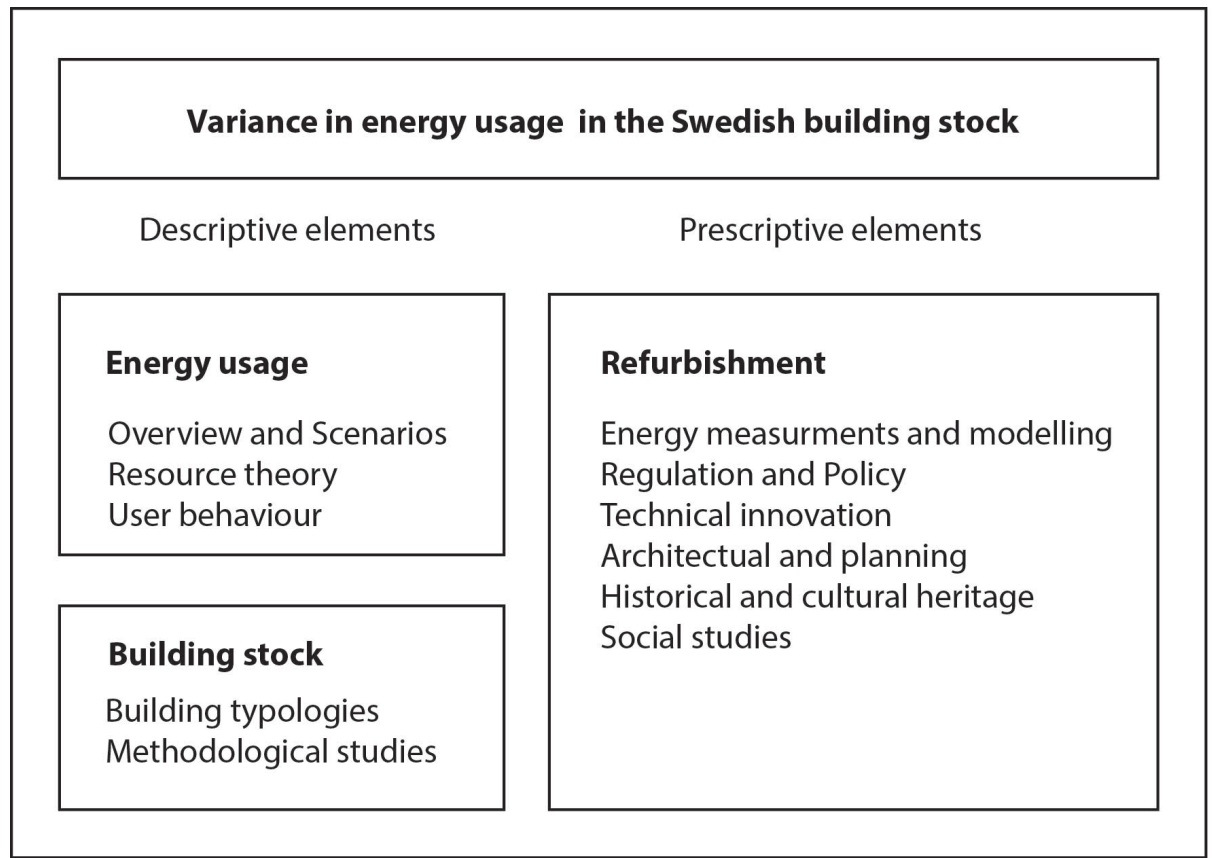

Figure 1: Systematization of Swedish contemporary literature relating to the variance in energy usage in the Swedish building stock. This figure is not conclusive or comprehensive, and there are studies that use multiple of the elements in one study.

This paper presents background information on energy usage and refurbishment status of the Swedish building stock in Chapter 1. Chapter 2 describes the method used when conducting this literature review. In Chapter 3 the contemporary building stock research is described, in part using contemporary disagreements amongst scholars. Finally Chapter 4 contains conclusions and identified research gaps.

\section{Method}

Under the central topic of variance in energy usage in the building stock papers, theses, and reports published the last five years have been read and summarized. To focus the review the following research questions were used:

- RQ1: What is the current energy usage status of the building stock?

- RQ2: What are the universities/institutions that do research on the Swedish building stock? What are their current research foci?

- RQ3: What are the current main issues in research on the building stock? What is the status on the debate about building stock typologies?

Reports from, and contacts with, the Swedish Energy Agency (Energimyndigheten), Boverket, and Swedish Bureau of Statistics (SCB) have primarily answered RQ1.

RQ2 was addressed by categorizing the literature as can be seen in table 1 . The authors of prominent works at Swedish universities and institutes were contacted for further detail of current activity and to ensure comprehensiveness of the coverage. Building stock research is a broad area that is studied in several disciplines and there are several topics that are currently relevant. The separation of the literature into research topics is done to answer RQ3. This separation is further described in chapter 4, Swedish building stock research. 
Table 1: Coverage and Spread of the Papers, Theses, and Reports Behind this Paper

\begin{tabular}{lll}
\hline Contacted universities and institutes & Disciplines & Topic categories \\
\hline Chalmers & Building physics & Energy measurements and modeling \\
Gothenburg University & Construction & Typology and methodology \\
Royal Institute of Technology (KTH) & Architecture and planning & Overview and Scenarios \\
Lund University & Urban studies & Regulations, certification and policy \\
Uppsala University & Physical resource theory & Social and cultural aspects \\
Technical Research Institute of Sweden (SP) & Environmental Strategies Research & Cultural heritage, architecture and history \\
Mid Sweden University & & Technical innovation \\
Umeå University & & Studies using EPC data \\
Swedish Environmental Research Institute (IVL) & & Demand side management and user focus \\
\hline
\end{tabular}

\section{Limitation}

As can be seen in figure 1 in the Introduction, the prescriptive studies of building stock relate to retrofitting of the building stock in one way or another. Building stock perspectives are less in focus in academic work on construction of new building. The research on new construction is not studied in this paper.

Economical and legal perspectives on building stock beyond energy performance have not been studied in detail in this literature review. A transdisciplinary research project with researchers in these fields could provide increased understanding of opportunities for energy efficiency measures. However, this is not within the scope of this review article.

\section{Energy Usage in Swedish Residential Building Stock}

The Betsi study (Boverket 2010) state that the share energy used in the Swedish building stock which is commonly stated to be $40 \%$ is overestimated. In figure 2 , the decreasing energy usage in the residential building stock, and the energy usage for heating per square meter can be seen.

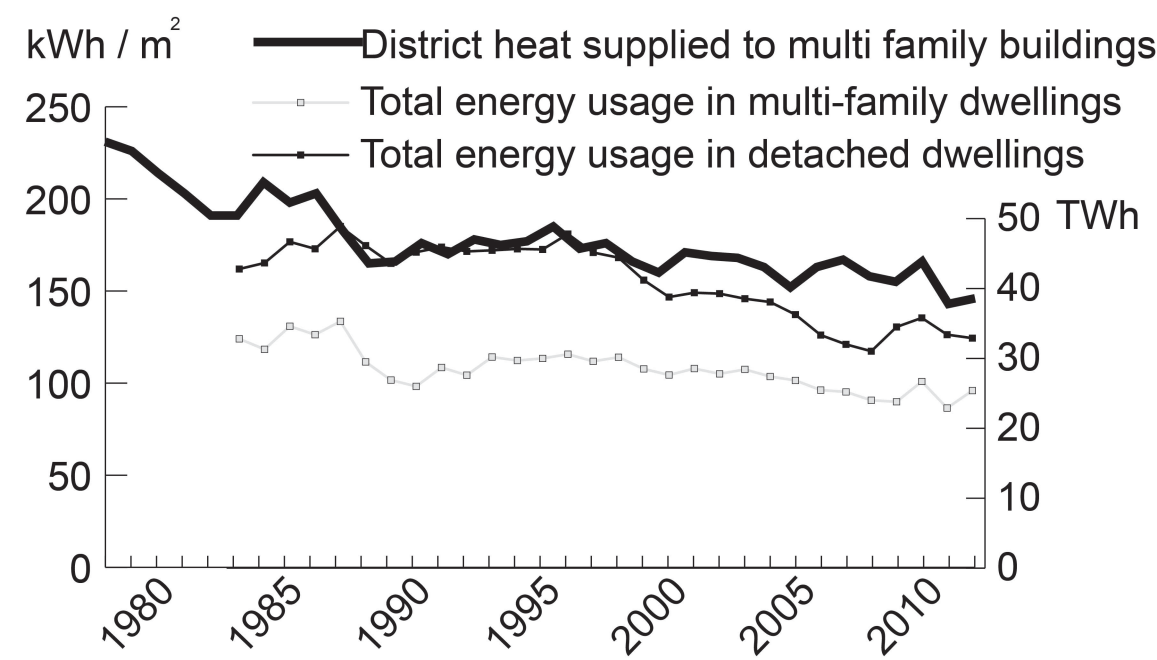

Figure 2: Heat Supplied through District Heating per square meter to Swedish Dwellings (Swedish Energy Agency 2013a) and Heating of Swedish Housing Stock (Swedish Energy Agency 2013b).

In Figure 2, the data for district heat supplied to multi-family buildings comes from a longitudinal survey by Swedish Energy Agency (2013a) since 1980, in which 8000 buildings with district heating was selected randomly every year. The reasons for this reduction are: improved energy performance by retrofitting; new construction and demolition; installation of heat pumps; and the increase of district heating, which makes heat losses at the production phase 
disappear in the calculation (the energy losses in heat production no longer happens in the building $)^{2}$.

In terms of heating the Betsi study (Boverket 2010) concludes that the goals (Swedish Government 2008) to improve energy efficiency of the building stock by $20 \%$ by 2020 will be reached. As will the goal to reduce $\mathrm{CO}_{2}$ emissions of the building stock by 40\% (1990 as a reference). However, electricity usage has increased during the last decade primarily due to installation of heat pumps and more household appliances. This has also been noticed as a challenge for the building stock development (Marsh, Larsen, and Kragh 2010). Total energy usage of Swedish dwellings is displayed in figure 3, including the energy loss that occurs in the production and distribution of district heat. In addition it should be noted that the residential building stock increased with 590 thousand dwellings, 17\%; that the population increased with 1.3 million, 16\%; and the average area of new built detached dwelling increased $48 \mathrm{~m}^{2}, 33 \%$.

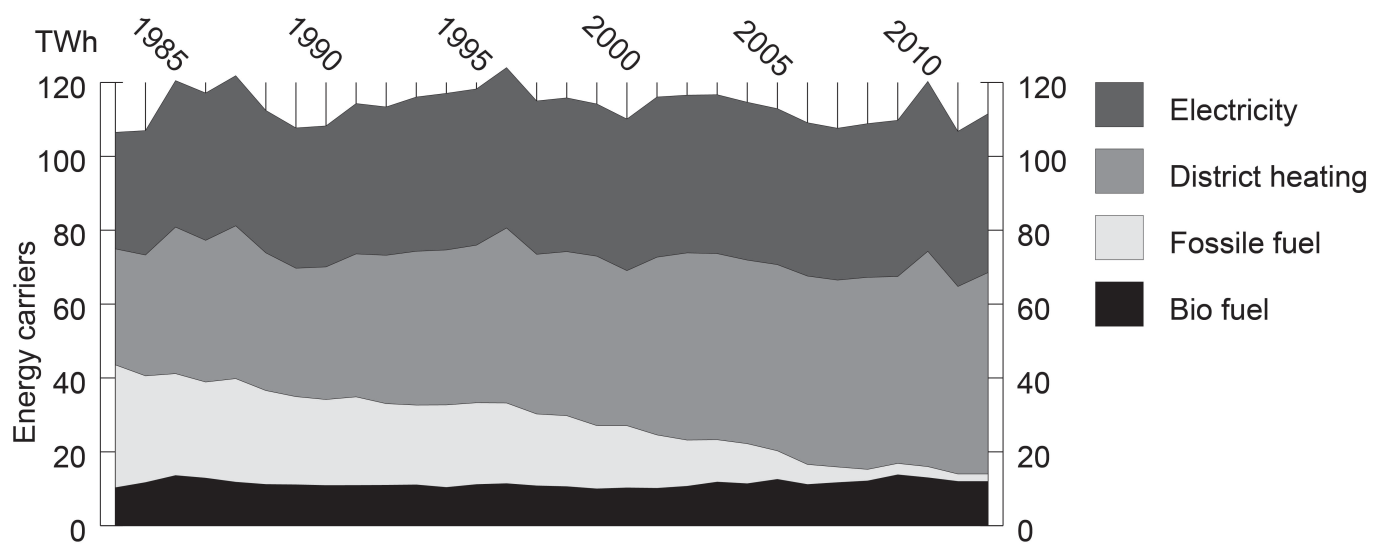

Figure 3: Energy carriers for the Swedish residential building stock, including household electricity (Swedish Energy Agency 2013b).

These observations compare well with conclusions by European scholars that have described energy usage issues in the residential building stock. A number of scholars (Kohler and Hassler 2012; Marsh, Larsen, and Kragh 2010; Sandberg, Bergsdal, and Brattebø 2011; Sunikka-Blank and Galvin 2012; Visscher, Majcen, and Itard 2012) are concluding that the energy usage in the building stock is not decreasing as predicted or even decreasing at all. This is due to: User behavior, increased comfort, increased living space, and over-heating. Kohler and Hassler (2012) stresses the importance of having a clear understanding of building stocks in different countries with a differentiated approach to retrofitting not based on frameworks for new construction.

Sandberg et al. (2011) argues for the inclusion of "efficient usage" next to "energy efficiency" as a parameter in the analysis of building stock by adding habitation area per capita to the measure of energy efficiency. The household size is also a parameter of importance when considering efficient usage. Relevant for this argument is that shared space use a forth of the energy compared with individually owned space (Danielski 2012). Furthermore, Marsh et al. (2010) also argue for "efficient use" and request future research to focus on over-heating. These are arguments that fit well into the debate on focusing on "sufficiency" rather than "efficiency" (Princen 2005; Sachs 2007).

In figure 3, it can be seen that energy from district heating is an increasingly important heat source for buildings. It is relevant to describe how this heat has been produced, see figure 4 . The total development of GHG intensity for district heating is calculated by using environmental

\footnotetext{
${ }^{2}$ Personal discussion, March 15th 2014, with Lars Nilsson at the Swedish Energy Agency
} 
impact factors in $\mathrm{CO}_{2} \mathrm{~g} / \mathrm{kWh}$. Heat from burning waste has been calculated as more carbon neutral than other fossil energy sources.

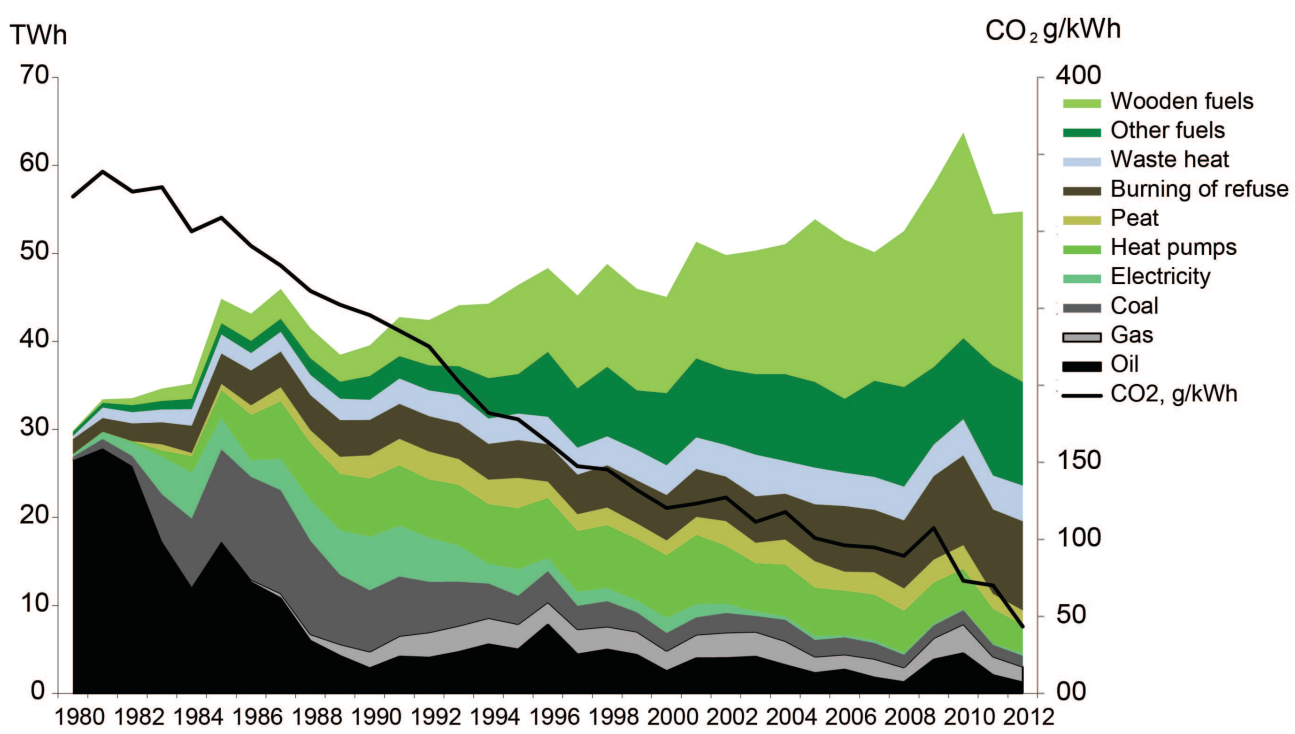

Figure 4: The composition of energy carriers used in district heating production as presented by the District Heating in Sweden (2014). The oil crisis 1979 explains the switch to other energy sources during the 1980's. An increase in electricity price thereafter made it profitable to replace direct resistive electric heating with heat pumps. A more detailed study of district heating and the building stock of Stockholm was made by Shahrokni et al. (2014).

The increased district heat coverage and the change in heating sources of district heating contribute greatly toward the $40 \%$ GHG emission reduction target of Swedish Government (2008). However, relying heavily on district heating from burning of refuse demotivates reduction of waste production and alteration to higher grades of waste recycling (Ordonez 2014).

\section{Energy Usage Reducing Retrofitting}

The majority of the buildings of 2050 already exist today (Stein and Harderup 2010). Wang and Martinac (2013) estimate that $80 \%$ of the energy usage in the building stock in 2050 will be in buildings already built today. Focusing on retrofitting is key to reducing the energy usage in the building stock (Boverket 2010) and has also received attention in academia due to the emphasis in the IPCC report.

A conclusion of this literature study is that a larger focus in academia is placed on retrofitting, especially in the building stock from the Million Homes Program ${ }^{3}$ era. In Sweden the EPC data contain measured energy usage for most buildings in the building stock. An initial analysis of the EPCs of all buildings in Gothenburg makes it possible to map in which buildings energy is used and to which extent. As can be seen in figure 5, a considerable share of the energy use is taking place in buildings from the Million Homes Program since more buildings were built during this era.

\footnotetext{
${ }^{3}$ During the period 1961-1975 a large national initiative focused on building one million dwellings to cover an urgent need (Hall 2005).
} 


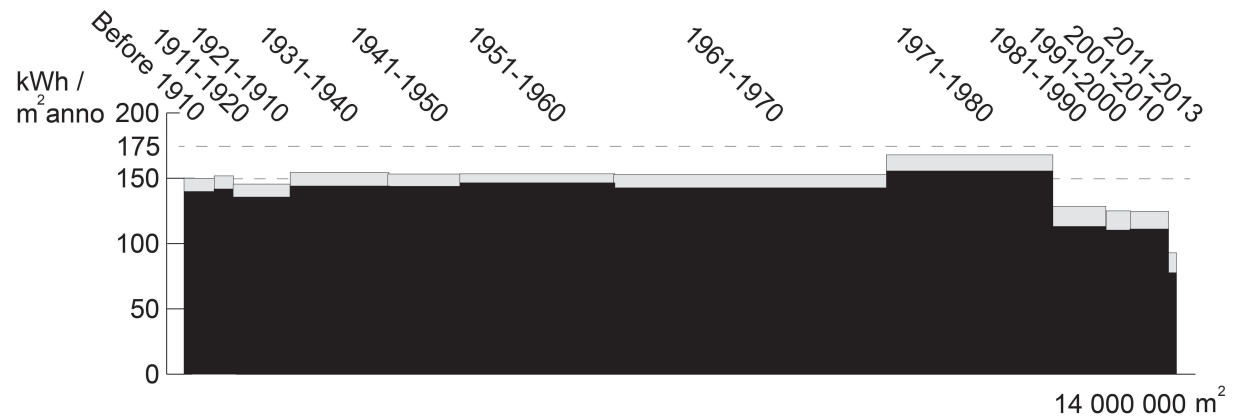

Figure 5: District heating energy and electricity (grey) in Gothenburg apartment buildings divided in age groups. The data is from the EPCs of buildings in Gothenburg extracted the $1^{\text {st }}$ of May 2014.

As can be seen in figure 5, average energy usage is fairly constant in the building age groups. This was also found by Wahlström (2015), which gathered EPC data on a national level. Within the age groups the annual energy usage per square varies as can be seen in figure 6 .

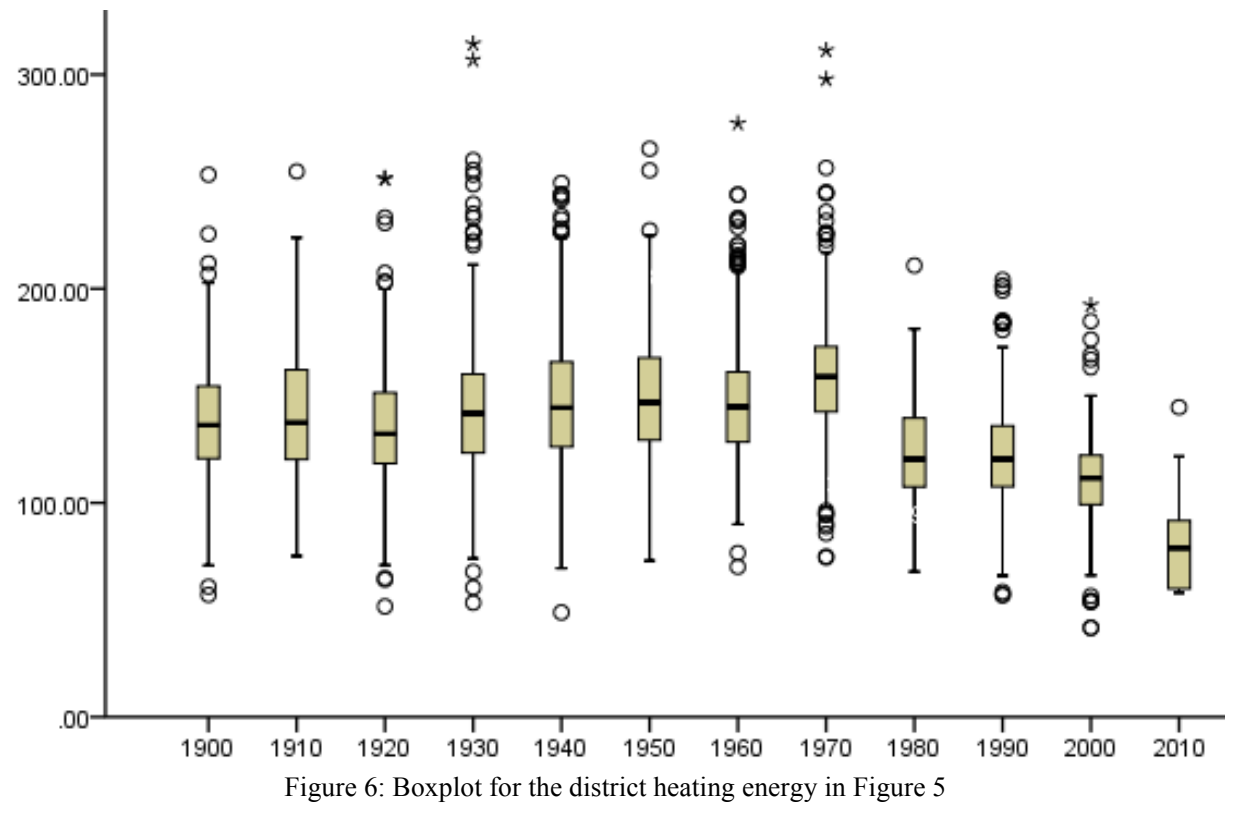

Due to the combined needs of retrofitting for aging buildings and for energy saving purposes there have been several initiatives to organize the retrofitting process. Milparena (Chalmers, SP), Bebo (Swedish Energy Agency), Square (Palonen 2010), Reesbe (Gälve University), Secure (Jarnehammar et al. 2008), Sveriges byggindustrier, Siren (chaired by Lund University) are some of the larger initiatives.

Even though there are numerous individually well monitored retrofitting projects it is difficult to generate an overview of the energy usage reducing measures applied in the building stock, since it is not required to register retrofitting for energy usage reduction. In recent years there has been an increase in data availability due to smart meters, cheaper meters, and wireless technologies. More measurements, more powerful calculation tools, and more modeling research has created the opportunity to create larger models of the building stock. Recent studies that apply the research method of Kohler and Hassler (2002) on the Swedish building stock are: 
- Brown et al. (2013) have made a detailed analysis of the difference retrofit package differences in three different types. They also analyzed Betsi data to assess different retrofit options and added a LCA dimension (Brown, Olson, and Malmqvist 2014).

- Mata (2013) made an a study on the Swedish building stock based on the Betsi study.

- Wang (2013) made a study on a retrofit packages in four different slab block building types.

These studies also build on the Swedish environmental rating tool Miljöbyggnad constructed by Sweden Green Building Council 2009 (Malmqvist et al. 2011).

One of the larger retrofitting studies was conducted in the BOOM project from 2000 till 2003. This study includes an overview of numbers of renovated dwellings, areas for different time periods, estimated renovation needs and costs, estimations of different renovation measures already taken related to buildings of different time periods (Boverket 2003).

\section{Swedish Building Stock Research}

Energy usage in the building stock is studied in, or relates to, several different disciplines. In table 2 the key contemporary governmental directives, datasets, and investigations are presented (Section 1-3), followed by literature divided in thematic groups. The literature does overlap and some studies are of transdisciplinary character. Table 2 is not an exhaustive record of all documents reviewed, but it identifies primary texts and scholars in each branch of literature from Swedish universities that has been part of this literature review. Most scholars have written several papers in their fields, in table 2 the most prominent work; theses and larger reports are given priority.

Section 4, Energy Measurements and Modeling, studies comparisons of measured and modeled energy usage. Section 5, Typology and methodology studies outline strategies for conducting larger models of the building stock. Studies concerned with Overview and Scenarios, applies modeling and sometimes typologies to evaluate future development based on certain scenarios.

Section 7, Regulation, Certification, and Policy, from the disciplines economics and urban studies that gathers studies that primarily use building stock data to give decision support. Research groups in various forms of urban studies and architecture have also produced several investigations on Social and Cultural Aspects, Section 8, that relate to the environmental upgrading of building stock.

Researchers that address Cultural Heritage, Architecture, and History, of building stocks are gathered in section 9 .

Section 10, Technical Innovation requires a comment on delimitation. This category gathers studies from building physics and construction, which all investigate technologies and take a larger perspective on the building stock. This also includes studies that investigate case studies of high environmental profile. However, studies that focus on specific technical innovations without a building stock context have not been included.

As mentioned in the introduction chapter, increasing amounts of energy usage data has made it clear that user behavior accounts for much variance in energy usage in the building stock. Section 11, Demand Side Management and User Focus, gather studies that focus on user behavior either descriptively in statistical studies or prescriptively in studies from design professions.

Section 12 has been added specifically because the next step in the research project, in which this paper belongs, is to use the EPC data for analysis. 
Table 2: Overview of Swedish Literature on Energy Usage in the Building Stock Produced the Past Decade

\begin{tabular}{|c|c|c|}
\hline $\begin{array}{l}\text { 1. Key governmental } \\
\text { policy documents and } \\
\text { directives }\end{array}$ & $\begin{array}{l}\text { Proposition } \\
(2008) / 09: 162 \\
\text { DIRECTIVE } \\
(2010) / 31 / \mathrm{EU}\end{array}$ & $\begin{array}{l}\text { En sammanhållen klimat- och } \\
\text { energipolitik - Klimat } \\
\text { On the energy performance of buildings }\end{array}$ \\
\hline $\begin{array}{l}\text { 2. Key ongoing empiric } \\
\text { studies performed by } \\
\text { governmental institutions }\end{array}$ & $\begin{array}{l}\text { Boverket } \\
\text { Swedish Energy } \\
\text { Agency }\end{array}$ & $\begin{array}{l}\text { EPC (Energideklarationen) } \\
\text { Energistatistik för småhus och } \\
\text { flerbostadshus }\end{array}$ \\
\hline $\begin{array}{l}\text { 3. Key governmental } \\
\text { research initiatives and } \\
\text { summaries performed } \\
\text { the last decade }\end{array}$ & $\begin{array}{l}\text { Boverket (2014) } \\
\text { Boverket (2010) } \\
\text { Boverket (2003) } \\
\text { Swedish Energy } \\
\text { Agency (2013c) } \\
\text { Swedish Energy } \\
\text { Agency (2009) } \\
\text { Formas (2012) } \\
\text { IVL (2012) }\end{array}$ & $\begin{array}{l}\text { Socialt hållbar stadsutveckling- en } \\
\text { kunskapsöversikt } \\
\text { Betsi } \\
\text { Bättre koll på underhåll } \\
\text { Halvera Mera } \\
\text { End-use metering campaign in } 400 \\
\text { households in Sweden } \\
\text { Miljonprogrammet - Utveckla eller } \\
\text { avveckla } \\
\text { Energieffektivisering av Sveriges } \\
\text { flerbostadshus }\end{array}$ \\
\hline $\begin{array}{l}\text { 4. Energy measurements } \\
\text { and modelling }\end{array}$ & \multicolumn{2}{|c|}{$\begin{array}{l}\text { (Bartusch et al. 2012; Brown, Olson, and Malmqvist 2014; Danielski } \\
\text { 2012; Sjögren, Andersson, and Olofsson 2009; Sjögren, Andersson, } \\
\text { and Olofsson 2007; Wang 2013; Thuvander 2002) }\end{array}$} \\
\hline $\begin{array}{l}\text { 5. Typology and } \\
\text { methodology }\end{array}$ & \multicolumn{2}{|c|}{$\begin{array}{l}\text { (Kim B Wittchen, Lone Mortensen, and Tove Malmquist 2012; } \\
\text { Lundin, Andersson, and Östin 2004; Mata 2013; Norrström 2011) }\end{array}$} \\
\hline $\begin{array}{l}\text { 6. Overview and } \\
\text { Scenarios }\end{array}$ & \multicolumn{2}{|c|}{$\begin{array}{l}\text { (Johansson, Nylander, and Johnsson 2007; Mata 2013; Nässén and } \\
\text { Holmberg 2013; Nässén, Sprei, and Holmberg 2008; Shahrokni, } \\
\text { Levihn, and Brandt 2014; Svenfelt, Engström, and Svane 2011) }\end{array}$} \\
\hline $\begin{array}{l}\text { 7. Regulations, } \\
\text { certification and policy }\end{array}$ & \multicolumn{2}{|c|}{$\begin{array}{l}\text { (Blomé 2010; Cerin, Hassel, and Semenova 2012; Högberg 2011; } \\
\text { Lind 2012; McCormick and Neij 2009; Nair, Gustavsson, and } \\
\text { Mahapatra 2010a; Thuvander et al. 2012; Toller et al. 2013; } \\
\text { Wahlström, M 2015; Wallhagen 2010) }\end{array}$} \\
\hline $\begin{array}{l}\text { 8. Social and cultural } \\
\text { aspects }\end{array}$ & \multicolumn{2}{|c|}{$\begin{array}{l}\text { (Andersson, Bråmå, and Hogdal 2009; Bradley 2009; Femenías and } \\
\text { Lindén 2012; Hagbert, Mangold, and Femenías 2013; Lind et al. } \\
\text { 2014; Molina and Westin 2012; Olsson 2012; Stenberg 2012; } \\
\text { Törnquist, Olsson, and Claesson 2012; Wangel 2012) }\end{array}$} \\
\hline $\begin{array}{l}\text { 9. Cultural heritage, } \\
\text { architecture and history }\end{array}$ & \multicolumn{2}{|c|}{$\begin{array}{l}\text { (Gohardani 2014; Hall and Vidén 2005; Norrström 2011; Tunström } \\
\text { 2009) }\end{array}$} \\
\hline 10. Technical innovation & \multicolumn{2}{|c|}{$\begin{array}{c}\text { (Åberg and Henning 2011; Anna Jarnehammar, Ivana Kildsgaard, } \\
\text { Erik Prejer 2011; Karlsson and Moshfegh 2007; Kramers 2012; } \\
\text { Langer and Bekö 2013; Pavlovas 2006; Sartori and Hestnes 2007; } \\
\text { Stein and Harderup 2010; Svane 2013) }\end{array}$} \\
\hline $\begin{array}{l}\text { 11. Demand side } \\
\text { management and user } \\
\text { focus }\end{array}$ & \multicolumn{2}{|c|}{$\begin{array}{c}\text { (Mahapatra, Nair, and Gustavsson 2011; Miafodzyeva, Brandt, and } \\
\text { Andersson 2013; Nair, Gustavsson, and Mahapatra 2010b; } \\
\text { Vassileva, Wallin, and Dahlquist 2011) }\end{array}$} \\
\hline $\begin{array}{l}\text { 12. Studies using EPC } \\
\text { data }\end{array}$ & \multicolumn{2}{|c|}{$\begin{array}{l}\text { (Bonde and Song 2013; Brown et al. 2013; Cerin, Hassel, and } \\
\text { Semenova 2012; Claesson 2011; Högberg 2011; Murphy 2013; } \\
\text { Svensson 2013; Wahlström, M 2015; Stensson 2014) }\end{array}$} \\
\hline
\end{tabular}




\section{Academic Differences in Viewpoints Among Environmental Retrofitting Studies}

Another result of the literature study is an observation of academic differences in view point among contemporary scholars and practitioners. These differences are only rarely expressed in detail. The purpose of gathering them in this chapter is to bring an understanding of what issues are currently relevant.

\section{Sustainable Development Boundaries For Retrofitting Projects In The Million}

\section{Homes Program}

Most all scholars and practitioners agree that retrofitting should be conducted in the Million Homes Program, but there are different opinions on what the primary concerns are. Some projects focus on technical solutions, of which previously mentioned are Bebo, ReBo, and Milparena. Furthermore, as mentioned in the Introduction and is pointing out in appendix 1 "The societal revenues and costs of improved energy efficiency" by Boverket (2010) the potential GHG emission reduction is less than assumed in target documents.

Another perspective that is stressed by Bradley (2009), Wangel (2012), Stenberg (2012), and Mangold (2013) is the importance of social justice when addressing GHG emission reduction in the Million Homes Program. Furthermore the per person GHG emission of inhabitants in the Million Homes Program is less than the average citizen (Lettenmeier et al. 2012).

When looking at figure 5 a conclusion is that there are possibilities to reduce GHG emissions by focusing on multi-family-buildings from the Million Homes Program era. However, of the buildings from the Million Homes Program $30 \%$ are single family detached buildings (Hall and Vidén 2005). More importantly, even though a substantial part of the energy usage in the building stock is taking place in the Million Homes Program, the per person contribution to GHG emissions is less there compared with the overall average (Lettenmeier et al. 2012). As Bradley et. al (2008, p. 69) writes "The environmental (in)justices is crucial to nuance the mainstream, consensus-oriented sustainability discourse in Sweden". Future studies on retrofitting of multi-family-buildings for the purpose of reducing GHG emission need to have a component of social justice (Mangold et al. 2014). Maintenance of the Million Homes Program is certainly needed, but when retrofitting is done in large scale there are risks of renoviction (Molina and Westin 2012; Lind et al. 2014). 


\section{To Make Extensive Investments in Lumped Projects or Invest Through Targeted Measures}

By making extensive investments that come as a package it is possible to reach more decreased energy usage reduction. This is the key method of the governmental project Halvera Mera (Swedish Energy Agency 2013c) to reach the $50 \%$ reduction of energy usage needed to reach governmental targets Swedish Government (2008)

Gårdsten is one of the examples of a extensive project that included heating, ventilation, water and waste system upgrades while also including inhabitant involvement, social justice and quality of life perspectives (Pavlovas 2006).

Bolmé, Hans Lind, Wang, and Brown argue that the most cost effective measures will be to split the retrofitting measures in subgroups. This is often emphasized by real estate maintainers (Formas 2012). Blomé and Lind (2011), in Malmö, write together and separately (Blomé 2010; Lind 2012) about maintenance in the Million Homes Program. They take an economic point of view and argue for separated and targeted investments.

\section{Governmental Subsidies To Promote Energy Efficient Technologies In Refurbishment Projects}

Investments for retrofitting of the Million Homes Program is called for by politicians, practitioners as well as scholars (Formas 2012). However, there are many ways of conducting investments. Governmental subsidies are one of the ways commonly proposed, amongst some of the discussed alternatives are: Investments in Allmännyttan (Pavlovas 2006), or subsidies for retrofitting for the purpose of reducing GHG emission, as conducted during OFFROT (Boverket 2009a).

Hans Lind (2012) argues that subsidies benefit companies that have not maintained their building stock.

Real estate companies in general are positive to subsidies, as this will enable renovations regardless of the previous levels of maintenance. In "The Million Homes Program - Develop or demolish" (Formas 2012) real estate maintainers argue for subsidies to be given for targeted measures to be carried out.

Boverket (2009a) conclude that the OFFROT project was too short to be comprehensively evaluated as a strategy for subsidies for energy usage reducing measures. 


\section{Energy Focus or GHG Focus}

Boverket (2010) describes the separate targets and perspectives of national security and climate change impact. As can be seen in figures 2, 3, and 4 the Swedish GHG emission targets are relatively easily reachable due to existing district heating system, water and nuclear power. Focusing on reducing energy usage in the building stock can be done to decrease dependency on non-domestic energy sources and to reduce costs.

This difference constitutes the dissimilarities in targets of "Nearly zero-energy buildings" and "Carbon Neutral Buildings." EU (2010) has a clear focus on "Nearly zero-energy buildings." The implementation of heat pumps has achieved reduction of energy usage in the building stock (Meggers et al. 2012). However using heat pumps would not make buildings "carbon neutral." Kibert and Fard (2012) have made a review article that distinguishes these strategies for European policy.

This is essentially not a disagreement but rather two different viewpoints with different system boundaries. Focusing on energy usage in the building sets a narrow system boundary, which does not consider the source of the energy. An even wider perspective would be to take a life-cycle perspective on the building itself.

\section{Gaps and Possibilities in the Swedish Research Field}

The European EPC datasets are contemporarily relevant research materials. There are several studies that have analyzed EPC data, see table 2, but no study has yet been made with the purpose of using EPC data to describe the building stock. Important in such a study will be to understand the shortcomings of the EPC. During conversations with practitioners it was mentioned that the quality of the EPC data is poor due to lack of economic incentive for quality. These claims need to be investigated with scientific rigor deeper than conducted by Boverket (2009b).

Sjögren (2009) have applied a method of explaining energy usage variance in building stock based on total heat loss coefficients derived from energy usage bills coupled with building specifications found in E-nyckeln $(\mathrm{N}=2500)$, a dataset of building characteristics similar to EPC. Degree month and energy usages are plotted. The derivative of the curve in the degree month / energy usages plot gives a total heat loss coefficient of the building, K-value. The K-value of the building could be explained by separating the different energy usages in the buildings into categories of varying temperature dependence. A regression analysis for dependencies of this derivative would point at variance in energy usage in the building stock. This method can be applied to energy usage data coupled with EPC data. A way of doing this at a larger scale is to create building groups for which Gothenburg energy would supply energy usage data. A weighting system based on building area could be used.

As written in the chapter 3 there is a group of scholars that claim retrofitting for the purpose of reducing GHG emission might cause aggravated conditions for socio-economically exposed 
groups in society. These studies are often based on qualitative data (Bradley 2009). A quantitative study on building stock and energy usage that takes socio-economic factors into consideration is requested.

There seems to be little overview of energy reducing retrofitting in Sweden. There are many case studies. But there are no statistics gathered on reduced energy usage by the authorities. Michelsen and Müller-Michelsen (2010) studied energy usage reduction through retrofitting in the German building stock, a similar study on the Swedish building stock would give provide and understanding on the energy usage development of the building stock.

The ownership structure of Million Homes Program building stock has been changing the past decade toward the private sector. This has facilitated some retrofitting processes in some areas, while it demotivated some retrofitting (Hall and Vidén 2005). The policy aspects of motivations behind energy usage reducing retrofitting is important to analyze since there are large variations amongst actors (Högdal 2013). In the first of the appendixes in the Betsi study (Boverket 2010) the market failures are separated and analyzed. The variations in energy usage for buildings with different ownership structures would give useful overview of potentials and an understanding of the importance of varying incentives.

\section{Conclusions}

This paper has showed that the energy usage in the Swedish residential building stock has varied between $100 \mathrm{TWh}$ and $120 \mathrm{TWh}$ over the last three decades. The residential building stock has become more energy efficient in terms of heating, but more energy is used for household electricity, increased living space and population increase. The $20 \%$ energy usage reduction target of Swedish Government (2008) will be reached chiefly due to installation of heat pumps and since the target is measured in heating per square meter. The target of reducing GHG emissions from the building stock by $40 \%$ will be reached chiefly due to the change of heating source and increased coverage of district heating.

When multi-family buildings in Gothenburg in the EPC data are grouped according to decade of construction the energy usage per square meter varies between 130 and $150 \mathrm{kWh} / \mathrm{m}^{2}$ year. A comparison with actual supplied energy for heating is required if the EPC data is to be used to describe energy usage in the building stock.

Other interesting possibilities in the Swedish building stock research field are quantitative studies on energy usage in the building stock that takes socio-economic factors and crowdedness into consideration, overview of energy usage reducing retrofitting and variations in energy usage for buildings with different ownership structures. These are all fields that are considered for future research in the group.

\section{REFERENCES}

Åberg, Magnus, and Dag Henning. 2011. “Optimisation of a Swedish District Heating System with Reduced Heat Demand due to Energy Efficiency Measures in Residential Buildings." Energy Policy 39 (12): 7839-52.

Andersson, Roger, Åsa Bråmå, and Jon Hogdal. 2009. Poor and Rich - Segregated City. Movement and Segregation Dynamics in Gothenburg 1990-2006 (Fattiga Och RikaSegregerad Stad. Flyttningar Och Segregationens Dynamik I Göteborg 1990-2006). Gothenburg city (Göteborgs stad).

Anna Jarnehammar, Ivana Kildsgaard, Erik Prejer, John. 2011. Kunskapsinventering Avseende Resurseffektiviserande Åtgärder Inom Befintlig Bebyggelse (Knowledge Inventory in Regards to Resource Effective Measures in the Built Environment). B1960. IVL. 
Bartusch, Cajsa, Monica Odlare, Fredrik Wallin, and Lars Wester. 2012. "Exploring Variance in Residential Electricity Consumption: Household Features and Building Properties." Applied Energy 92: 637-43.

Blomé, Gunnar. 2010. Ekonomiska Effekter Relaterade till Åtgärder I Bostadsområden-Två Praktiska Exempel (Economic Impacts Related to Measures in Residential Areas - Two Practical Examples). Boverket.

Blomé, Gunnar, and Hans Lind. 2011. "The Return of the Swedish Slumlord: Analysis of a Recent Case." Royal Institute of Technology, Stockholm.

Bonde, Magnus, and Han-Suck Song. 2013. "Is Energy Performance Capitalized in Office Building Appraisals?” Property Management 31 (3): 200-215.

Boverket. 2003. Better understanding of maintenence (Bättre Koll På Underhåll).

Boverket. 2009a. Design eduction effects - Boverkets evaluation of OFFrot support (Utformningen Reducerade Effekterna - Boverkets Utvärdering Av OFFrotstödet).

Boverket. 2009b. Assessment of the EPC system (Utvärdering Av Systemet Med Energideklarationer).

Boverket. 2010. Betsi - Energy in the built environment - technical properties and calculations (Betsi - Energi I Bebyggelsen - Tekniska Egenskaper Och Beräkningar).

Boverket. 2014. Socially sustatinable city development (Socialt Hållbar Stadsutveckling)'

Bradley, Karin. 2009. "Just Environments - Politicising Sustainable Urban Development”. PhD Diss. KTH.

Bradley, Karin, Ulrika Gunnarsson-Östling, and Karolina Isaksson. 2008. "Exploring Environmental Justice in Sweden: How to Improve Planning for Environmental Sustainability and Social Equity in an 'eco-Friendly' Context.” Projections, MIT Journal of Planning 8: 68-81.

Brown, Nils WO, Tove Malmqvist, Wei Bai, and Marco Molinari. 2013. "Sustainability Assessment of Renovation Packages for Increased Energy Efficiency for Multi-Family Buildings in Sweden." Building and Environment 61: 140-48.

Brown, Nils WO, Stefan Olson, and Tove Malmqvist. 2014. "Screening Embedded Global Warming Potential for Renovation Actions Achieving 50\% Reduced Energy Demand in Swedisk Residential Building Stock."

Cerin, Pontus, L Hassel, and Natalia Semenova. 2012. "Energy Performance and Housing Prices." PRI-CBERN, Toronto.

Claesson, Joachim. 2011. Results and Methods Development of Energy Performance Certification of Buildings (Utfall Och Metodutvärdering Av Energideklaration Av Byggnader). CERBOF Projekt no. 72:

Commission, European. 2000. Green Paper - Towards a European Strategy for the Security of Energy Supply.

Danielski, Itai. 2012. "Large Variations in Specific Final Energy Use in Swedish Apartment Buildings: Causes and Solutions." Energy and Buildings 49: 276-85.

District Heating in Sweden. 2014. "Tillförd Energi Utveckling 1980-2012.” Last modified 19 of June. http://www.svenskfjarrvarme.se/Statistik-Pris/Fjarrvarme/Energitillforsel/Tillford-energi-utveckling-1980-2012/.

EU. 2010. On the Energy Performance of Buildings. 2010/31/EU.

Femenías, Paula, and Anna-Lisa Lindén. 2012. "Integrated Strategies to Overcome Market Barriers." Energy Efficiency in Housing Management: Policies and Practice in Eleven Countries, 16.

Formas. 2012. Miljonprogrammet-utveckla Eller Avveckla. Forskningsrådet Formas.

Gohardani, Navid. 2014. “An Approach towards Sustainable Building.” PhD Diss. KTH.

Hagbert, Pernilla, Mikael Mangold, and Paula Femenías. 2013. "Paradoxes and Possibilities for a 'Green' Housing Sector: A Swedish Case.” Sustainability 5 (5): 2018-35. 
Hall, Thomas, and Sonja Vidén. 2005. "The Million Homes Programme: A Review of the Great Swedish Planning Project.” Planning Perspectives 20 (3): 301-28.

Högberg, Lovisa. 2011. "Incentives for Energy Efficiency Measures in Post-War Multi-Family Dwellings." Licentiate Diss. KTH.

Högdal, Katarina. 2013. More reduction by 50 \% (Halvera Mera). Stockholm: BeBo.

Jarnehammar, Anna, Jeanette Green, Ivana Kildsgaard, Åke Iverfeldt, Peter Foldbjerg, Joe Hayden, and Ahto Oja. 2008. "Barriers and Possibilities for a More Energy Efficient Construction Sector." SECURE-Sustainable Energy Communities in Urban Areas in Europe, an Intelligent Energy Europe Project.

Johansson, P, A Nylander, and Filip Johnsson. 2007. "Primary Energy Use for Heating in the Swedish Building Sector-current Trends and Proposed Target.” Energy Policy 35 (2): $1386-1404$.

Karlsson, JF, and Bahram Moshfegh. 2007. "A Comprehensive Investigation of a Low-Energy Building in Sweden.” Renewable Energy 32 (11): 1830-41.

Kibert, Charles J, and Maryam Mirhadi Fard. 2012. "Differentiating among Low-Energy, LowCarbon and Net-Zero-Energy Building Strategies for Policy Formulation.” Building Research \& Information 40 (5): 625-37.

Kim B Wittchen, Lone Mortensen, and Tove Malmquist. 2012. "Building Typologies in the Nordic Countries." SBi 2012: 04, 83.

Kohler, Niklaus, and Uta Hassler. 2002. "The Building Stock as a Research Object." Building Research \& Information 30 (4): 226-36.

Kohler, Niklaus, and Uta Hassler. 2012. "Alternative Scenarios for Energy Conservation in the Building Stock.” Building Research \& Information 40 (4): 401-16.

Kramers, Anna. 2012. "Contribution of ICT to Climate Targets of Cities". Licentiate Diss. KTH.

Langer, Sarka, and Gabriel Bekö. 2013. "Indoor Air Quality in the Swedish Housing Stock and Its Dependence on Building Characteristics." Building and Environment 69: 44-54.

Lettenmeier, M., T. Hirvilammi, S. Laakso, S. Lähteenoja, and K. Aalto. 2012. "Material Footprint of Low-Income Households in Finland-Consequences for the Sustainability Debate." Sustainability 4 (7): 1426-47.

Lind, Hans. 2012. "Pricing Principles and Incentives for Energy Efficiency Investments in MultiFamily Rental Housing: The Case of Sweden." Energy Policy 49: 528-30.

Lind, Hans, Kerstin Annadotter, Folke Björk, Lovisa Högberg, and Tord af Klintberg. 2014. Sustainable Renovation Strategy in the Swedish Million Homes Programme: A Case Study.

Lundin, Mikael, Staffan Andersson, and Ronny Östin. 2004. "Development and Validation of a Method Aimed at Estimating Building Performance Parameters." Energy and Buildings 36 (9): 905-14.

Mahapatra, Krushna, Gireesh Nair, and Leif Gustavsson. 2011. "Energy Advice Service as Perceived by Swedish Homeowners." International Journal of Consumer Studies 35 (1): 104-11.

Malmqvist, Tove, Mauritz Glaumann, Åsa Svenfelt, Per-Olof Carlson, Martin Erlandsson, Johnny Andersson, Helene Wintzell, Göran Finnveden, Torbjörn Lindholm, and TorGöran Malmström. 2011. "A Swedish Environmental Rating Tool for Buildings." Energy 36 (4): 1893-99.

Mangold. 2013. "The Effect of Resource Sustainability Interventions on Social Sustainable Development in the Built Environment". Licentiate Diss.Chalmers University of Technology.

Mangold, Mikael, Greg Morrison, Robin Harder, Pernilla Hagbert, and Sebastien Rauch. 2014. "The Transformative Effect of the Introduction of Water Volumetric Billing in a Disadvantaged Housing Area in Sweden” 16. doi:doi: 10.2166/wp.2014.105. 
Marsh, Rob, Vibeke Grupe Larsen, and Mikkel Kragh. 2010. "Housing and Energy in Denmark: Past, Present, and Future Challenges.” Building Research \& Information 38 (1): 92-106.

Mata, Érika. 2013. "Modelling Energy Conservation and CO2 Mitigation in the European Building Stock." PhD Diss. Chalmers.

McCormick, Kes, and Lena Neij. 2009. "Experience of Policy Instruments for Energy Efficiency in Buildings in the Nordic Countries."

Meggers, Forrest, Hansjürg Leibundgut, Sheila Kennedy, Menghao Qin, Mike Schlaich, Werner Sobek, and Masanori Shukuya. 2012. "Reduce CO2 from Buildings with Technology to Zero Emissions." Sustainable Cities and Society 2 (1): 29-36. doi:10.1016/j.scs.2011.10.001.

Miafodzyeva, Sviatlana, Nils Brandt, and Mari Andersson. 2013. "Recycling Behaviour of Householders Living in Multicultural Urban Area: A Case Study of Järva, Stockholm, Sweden.” Waste Management \& Research, 0734242X13476746.

Michelsen, Claus, and Silke Müller-Michelsen. 2010. "Energieeffizienz Im Altbau: Werden Die Sanierungspotenziale Überschätzt? Ergebnisse Auf Grundlage Des Ista-IWHEnergieeffizienzindex." Wirtschaft Im Wandel 16 (9): 447-55.

Mol, A. P. J., and D. A. Sonnenfeld. 2009. The Ecological Modernisation Reader: Environmental Reform in Theory and Practice. London [etc.]: Routledge.

Molina, Irene, and Sara Westin. 2012. "Renoviction-Even in Sweden?: Four Case Studies on the Regeneration of Public Housing Estates."

Murphy, Lorraine. 2013. "The Policy Instruments of European Front-Runners: Effective for Saving Energy in Existing Dwellings?” Energy Efficiency, 1-17.

Nair, Gireesh, Leif Gustavsson, and Krushna Mahapatra. 2010a. "Factors Influencing Energy Efficiency Investments in Existing Swedish Residential Buildings.” Energy Policy 38 (6): 2956-63.

Nair, Gireesh, Leif Gustavsson, and Krushna Mahapatra. 2010b. "Owners Perception on the Adoption of Building Envelope Energy Efficiency Measures in Swedish Detached Houses.” Applied Energy 87 (7): 2411-19.

Nässén, Jonas, and John Holmberg. 2013. "On the Potential Trade-Offs between Energy Supply and End-Use Technologies for Residential Heating.” Energy Policy 59: 470-80.

Nässén, Jonas, Frances Sprei, and John Holmberg. 2008. "Stagnating Energy Efficiency in the Swedish Building sector-Economic and Organisational Explanations." Energy Policy 36 (10): 3814-22.

Norrström, Heidi. 2011. "Energy Efficiency and Preservation in Our Cultural Heritage." PhD Diss. Chalmers.

Olsson, Sören. 2012. Social Sustainability in a Planning Perspective (Social Hållbarhet I Ett Planeringsperspektiv). Gothenburg University.

Ordonez, Maria Isabel. 2014. "Turning Waste into Resources: Rethinking the Way We Discard Things". Licentiate, Chalmers University of Technology.

Palonen, Jari. 2010. SQUARE-A System for Quality Assurance When Retrofitting Existing Buildings to Energy Efficient Buildings.

Pavlovas, Vitalijus. 2006. "Energy Savings in Existing Swedish Apartment Buildings - Some Aspects on Demand Controlled Ventilation and Individual Metering." PhD Diss. Chalmers

Princen, Thomas. 2005. The Logic of Sufficiency. Vol. 30. MIT Press Cambridge, MA.

Sachs, Wolfgang. 2007. "Global Challenges: Climate Chaos and the Future of Development." IDS Bulletin 38 (2): 36-39.

Sandberg, Nina Holck, Håvard Bergsdal, and Helge Brattebø. 2011. "Historical Energy Analysis of the Norwegian Dwelling Stock." Building Research \& Information 39 (1): 1-15.

Sartori, I., and A. G. Hestnes. 2007. "Energy Use in the Life Cycle of Conventional and LowEnergy Buildings: A Review Article.” Energy and Buildings 39 (3): 249-57. 
Shahrokni, Hossein, Fabian Levihn, and Nils Brandt. 2014. "Big Meter Data Analysis of the Energy Efficiency Potential in Stockholm's Building Stock.” Energy and Buildings 78 (0): 153-64. doi:10.1016/j.enbuild.2014.04.017.

Sjögren, J.-U., S. Andersson, and T. Olofsson. 2007. "An Approach to Evaluate the Energy Performance of Buildings Based on Incomplete Monthly Data." Energy and Buildings 39 (8): 945-53. doi:10.1016/j.enbuild.2006.10.010.

Sjögren, J.-U., S. Andersson, and T. Olofsson. 2009. "Sensitivity of the Total Heat Loss Coefficient Determined by the Energy Signature Approach to Different Time Periods and Gained Energy." Energy and Buildings 41 (7): 801-8. doi:10.1016/j.enbuild.2009.03.001.

Stein, Johan, and Lars-Erik Harderup. 2010. "Concerns When Improving the Energy Efficiency of 1960s and 1970s Swedish Multi-Family Dwellings."

Stenberg, Erik. 2012. "Appendix E (page 67-71) for the Report Energy Efficiency Improvement of Swedsh Multi-family-dwellings: Challanges and Opportunities to decrease the energy usage by half till 2050 (Bilaga E (sid 67-71) till Rapport Energieffektivisering Av Sveriges Flerbostadshus: Hinder Och Möjligheter Att Nå En Halverad Energianvändning till 2050.)"

Stensson, Sofia. 2014. "Energy Efficency In Shopping Malls Some Aspects Based on a Case Study". PhD Diss. Chalmers University Of Technology.

Sunikka-Blank, Minna, and Ray Galvin. 2012. "Introducing the Prebound Effect: The Gap between Performance and Actual Energy Consumption." Building Research \& Information 40 (3): 260-73.

Svane, Örjan. 2013. "Energy Efficiency in Hammarby Sjöstad, Stockholm through ICT and Smarter Infrastructure-survey and Potentials.” On Information and Communication Technologies, 190.

Svenfelt, Åsa, Rebecka Engström, and Örjan Svane. 2011. "Decreasing Energy Use in Buildings by $50 \%$ by 2050 - A Backcasting Study Using Stakeholder Groups." Technological Forecasting and Social Change 78 (5): 785-96.

Svensson, Yvonne. 2013. Konsekvensutredning Med Anledning Av Ändringar I Boverkets Föreskrifter Och Allmänna Råd (2007:4) Om Energideklaration För Byggnader, BED 6. Boverket.

Swedish Energy Agency. 2009. End-Use Metering Campaign in 400 Households In Sweden. Energimyndigheten.

Swedish Energy Agency. 2013a. Energy Statistics for Multi-Dwelling Buildings ES 2013:03. Energy Statistics for Multi-Dwelling Buildings.

Swedish Energy Agency. 2013b. Summary of Energy Statistics for Dwellings and Nonresidential Premises.

Swedish Energy Agency. 2013c. Halvera Mera. Stockholm: BeBo.

Swedish Government. 2008. Regeringens Proposition 2008.

Thuvander, Liane. 2002. "Towards Environmental Informatics for Building Stocks". PhD Diss. Chalmers University Of Technology.

Thuvander, Liane, Paula Femenías, Kristina Mjörnell, and Pär Meiling. 2012. "Unveiling the Process of Sustainable Renovation." Sustainability 4 (6): 1188-1213.

Toller, Susanna, Annica Carlsson, Anders Wadeskog, Sofiia Miliutenko, and Göran Finnveden. 2013. "Indicators for Environmental Monitoring of the Swedish Building and Real Estate Management Sector.” Building Research \& Information 41 (2): 146-55.

Törnquist, Anders, Sören Olsson, and Staffan Claesson. 2012. A Socially Mixed Habitation in Gothenburg (Ett Socialt Blandat Boende I Göteborg).

Tunström, Moa. 2009. "Search for the good city: about construction of ideals and problems in Swedish city planning discussion (På Spaning Efter Den Goda Staden: Om 
Konstruktioner Av Ideal Och Problem I Svensk Stadsbyggnadsdiskussion)” PhD Diss. Örebro University.

UNEP. 2007. Buildings and Climate Change Status, Challenges and Opportunities.

Vassileva, Iana, Fredrik Wallin, and Erik Dahlquist. 2011. "Analytical Comparison between Electricity Consumption and Behavioral Characteristics of Swedish Households in Rented Apartments." Applied Energy.

Visscher, Henk, Dasa Majcen, and Laure Itard. 2012. "Effectiveness of Energy Performance Certification for the Existing Housing Stock." In RICS COBRA 2012, Proceedings of the Construction, Building and Real Estate Conference, Tempe, AZ: Arizona State University, 130-48.

Wahlström, M. 2015. "The Residential Value of Energy Efficient Housing."

Wallhagen, Marita. 2010. "Environmental Assessment of Buildings and the Influence on Architectural Design." Licentiate Diss. KTH.

Wang, Qian. 2013. "Toward Industrialized Retrofitting: Accelerating the Transformation of the Residential Building Stock in Sweden”. Licentiate Diss. KTH.

Wang, Qian, and Ivo Martinac. 2013. "The Application of LCCA toward Industrialized Building Retrofitting- Case Studies of Swedish Residential Building Stock." In Sustainability in Energy and Buildings, 931-46. Springer.

Wangel, Josefin. 2012. "Making Futures: On Targets, Measures and Governance in Backcasting and Planning." PhD Diss. KTH.

Westlund, P, C Armstrong-Darvik, M Bergdahl, A Elmroth, T Hallén, T Kåberger, P Marckert, J Nordling, and PE Petersson. 2012. "Energieffektivisering Av Sveriges FlerbostadshusHinder Och Möjligheter Att Nå En Halverad Energianvändning till 2050.” Academy of Engineering Sciences, Department for Infrastructure Planning.

\begin{abstract}
ABOUT THE AUTHORS
Mikael Mangold: PhD Student, Building Technology, Built Environment, Chalmers University of Technology, Gothenburg, Sweden
\end{abstract}

Magnus Österbring: Chalmers Technical University, Gothenburg, Sweden

Prof. Holger Wallbaum: Chalmers Technical University, Gothenburg, Sweden 